\title{
RESPONSE OF Epidendrum Ibaguense (ORCHIDACEAE) TO THE APPLICATION OF LIME RATES TO THE POT ${ }^{(1)}$
}

\author{
Donizetti Tomaz Rodrigues ${ }^{(2)}$, Roberto Ferreira Novais ${ }^{(3)}$, Víctor \\ Hugo Alvarez V. ${ }^{(3)}$, José Maria Moreira Dias ${ }^{(4)}$ \& Ecila Mercês de \\ Albuquerque Villani ${ }^{(5)}$
}

\begin{abstract}
In the best cultivation methods of orchids, in particular of the genus Phalaenopsis, liming is a common practice. The objective of this study was to evaluate the influence of lime rates $\left(0.0 ; 1.0 ; 2.0 ; 3.0 ; 4.0\right.$; and $5.0 \mathrm{~g} \mathrm{dm}^{-3}$ of substrate) applied to the cultivation substrate (xaxim) on the growth of Epidendrum ibaguense seedlings. In a greenhouse, 1-L plastic pots filled with $0.8 \mathrm{dm}^{3}$ of xaxim were irrigated such that no leachate was lost during the experiment. $\mathrm{N}, \mathrm{P}, \mathrm{K}, \mathrm{Ca}, \mathrm{Mg}, \mathrm{S}$, $\mathrm{Fe}, \mathrm{Zn}, \mathrm{B}$, and Mn contents in roots, stems and leaves were measured. Leachate was collected by applying a sufficient water volume to obtain $25 \mathrm{~mL}$ from each pot. Fourteen days after lime application of $3 \mathrm{~g} \mathrm{dm}^{-3}$, the $\mathrm{pH}$ of the collected leachate reached values above 7 and a value of 6.29 with the highest lime rate at the end of the experiment. The lime rate did not influence plant height, probably due to a $\mathrm{Zn}$ deficiency at high $\mathrm{pH}$ levels and a Ca deficiency in the control. Nevertheless, there was a large increase in leaf production, for number as well as for dry matter mass. There was no statistical difference between treatments in root dry matter production. Maximum dry matter production was obtained at a lime rate of $4.09 \mathrm{~g} \mathrm{dm}^{-3}$. Zinc concentrations diminished linearly with increasing lime rates; the concentrations in all treatments were below the levels suggested as adequate in the literature $\left(25-200 \mathrm{mg} \mathrm{kg}^{-1}\right)$. Nutrient concentrations in leaves indicated deficiency of $\mathrm{N}, \mathrm{S}$, and $\mathrm{B}$ at the highest lime rates $\left(4.0\right.$ and $\left.5.0 \mathrm{~g} \mathrm{dm}^{-3}\right)$, and of $\mathrm{Ca}$ in the treatment without liming.
\end{abstract}

Index terms: orchids, nutrition, liming, floriculture.

\footnotetext{
(1) Received for publication in January 2009 and approved in March 2010.

(2) Doctoral Candidate in Soil and Plant Nutrition, Soil Science Department, Federal University of Viçosa UFV. Av. PH Rolfs s/n, CEP 36570-000 Viçosa (MG). E-mail: donitom@yahoo.com.br

(3) Professor, Soil Science Department, UFV. E-mails: rfnovais@ufv.br; vhva@ufv.br

(4) Professor, Plant Science Department, UFV. E-mail: jmmdias@ufv.br

(5) Pos-Doctor, Soil Science Department, UFV. E-mail: ecilavillani@yahoo.com.br
} 


\title{
RESUMO: RESPOSTA DE Epidendrum ibaguense (ORCHIDACEAE) $\grave{A}$ APLICAÇÃO DE DOSES DE CALCÁRIO EM VASO
}

\begin{abstract}
Nos melhores cultivos de orquídeas é comum o uso de calcário, de modo particular daquelas do gênero Phalaenopsis. Neste trabalho, objetivou-se avaliar a influência de doses de calcário $\left(0,0 ; 1,0 ; 2,0 ; 3,0 ; 4,0\right.$ e 5,0 g dm $\mathrm{m}^{-3}$ de substrato) aplicadas sobre o substrato de cultivo (xaxim) no crescimento de mudas de Epidendrum ibaguense. Foram utilizados vasos plásticos de $1 \mathrm{~L}$ preenchidos com $0,8 \mathrm{dm}^{3}$ de xaxim em casa de vegetação, com irrigação controlada, de forma que não ocorressem perdas por lixiviação de nutrientes durante a condução do experimento. Foram determinados os teores de $\mathrm{N}, \mathrm{P}, \mathrm{K}, \mathrm{Ca}, \mathrm{Mg}, \mathrm{S}, \mathrm{Fe}, \mathrm{Zn}, \mathrm{B}$ e $\mathrm{Mn}$ em raizes, caules e folhas. Foi coletado um lixiviado a partir da aplicação de um volume de água suficiente para a coleta de $25 \mathrm{~mL}$ de cada vaso. Aos 14 dias após aplicação das doses de calcário, o pH do lixiviado coletado atingiu valores superiores a 7, a partir da dose de $3 \mathrm{~g} \mathrm{dm}^{-3}$, e apresentou valor de 6,29 para a maior dose de calcário no final do experimento. Não houve influência das doses de calcário na altura das plantas, provavelmente devido à deficiência de Zn em valores de $p H$ elevados e à deficiência de Ca na testemunha. Todavia, houve grande incremento na produção de folhas, tanto para número quanto para massa de matéria seca. Não houve diferença estatística para produção de matéria seca de raízes entre os tratamentos. A produção de matéria seca de folhas foi máxima com a aplicação de 4,09 $\mathrm{g} \mathrm{dm}^{-3}$ do calcário. Os teores de Zn diminuíram linearmente com o aumento da dose de calcário; todos os tratamentos apresentaram teores abaixo daqueles considerados adequados pela literatura (25-200 $\left.\mathrm{mg} \mathrm{kg}^{-1}\right)$. Os teores dos nutrientes analisados demonstraram deficiencias foliares de N, Se B para as maiores doses de calcário (4 e $5 \mathrm{~g} \mathrm{dm}^{-3}$ ) e de Ca no tratamento que não recebeu calcário.
\end{abstract}

Termos de indexação: orquídeas, nutrição, calagem, floricultura.

\section{INTRODUCTION}

The flower and ornamental plant market is a very dynamic sector in many countries. In Holland, for example, the business volume of this sector was seven billion dollars in 1994 (Matsunaga, 1995). The world flower and ornamental plant market moves around 100 billion dollars per year. The USA, Japan and Colombia stand out among the principal producers and exporters, while Switzerland and Norway are among the greatest consumers of flowers, with per capita consumption of over 150 dollars per year (Castro, 1998). On the other hand, in the Mercosur countries, per capita consumption is significantly lower: in Argentina, 25 dollars and in Brazil, only 6 dollars per year. Brazil, in 2007, had around 8,423 plant nurseries (protected and field nurseries) and 5,152 producers, moving 1.3 billion dollars per year in the production chain of flowers and ornamental plants. Brazilian exportations to Holland, USA, Japan, among others, are in the range of U\$ 35 million annually, corresponding to $2.7 \%$ of the total production of flowers and ornamental plants (Junqueira \& Peetz, 2008). In 2007, the exportation of orchid plants increased $43.6 \%$ compared to the previous year, corresponding to 233.91 thousand US dollars, mainly to the USA, Germany and Japan (Junqueira \& Peetz, 2008).

As could be expected, the nutrition and fertilization of ornamental plants for flower or seedling production is an aspect that has to date not been satisfactorily elucidated.

Studies on fertilization and nutrition have been carried out with the genus Phalaenopsis, a plant of Asian origin, nutritionally more demanding than other genera that grow and develop more slowly, such as Cattleya and Laelia. In the first case, some plants can have flowers in the first year, while the two genera cited only after the fifth year of age (Demundo, 2004). Research results have shown that concentrations between 1 and $2 \mathrm{~g} \mathrm{~L}^{-1}$ of water-soluble mineral fertilizer applied weekly by fertigation are sufficient for growth and development of the orchid genus Phalaenopsis (Wang \& Gregg, 1994; Wang, 1996; Amberger-Ochsenbauer, 1997; Wang, 2000). In a study of Wang \& Gregg (1994), different rates of Peters ${ }^{(6)}$ 20-20-20 (Peters Fertilizer Products, Fogelsville, Pa.) used in two flowering cycles of Phalaenopsis spp. resulted in differences in flower production and quality, which were proportionally larger with higher fertilizer rates.

Another point to consider is the important role of genetic variation of plants in fertilization response. Amberger-Ochsenbauer (1997) report excellent growth of Phalaenopsis with weekly applications of 0.4$1.5 \mathrm{~g} \mathrm{~L}^{-1}$ of $16-9-22$ water-soluble fertilizer, resulting

\footnotetext{
(6) Peters ${ }^{\circledR}$ is a commercial BRND of NPK + micronutrient fertilizers, often used in orchid cultivation.
} 
in plants with greater expression of floral stems. The response to fertilizer differed however, depending on the hybrid used and the results for number of flowers per stem were better in genetically improved plants.

Another relevant factor in orchid cultivation regarding water-soluble fertilizers such as Peters $₫$ is the deficiency of some nutrients in orchids, for example of $\mathrm{Ca}$ and S. Calcium deficiency in orchids causes death in growth regions such as the root and stem apex and increases plant susceptibility to pests and diseases (Novais \& Rodrigues, 2004).

For this reason, the addition of Ca to the substrate in Phalaenopsis cultivation is a common practice of American producers. In the studies of Wang (1996), $3 \mathrm{~g}$ of dolomitic limestone were added per $0.6-\mathrm{L}$ pot as basic treatment, which is equivalent to a lime application of $10 \mathrm{t} \mathrm{ha}^{-1}$ to soil $(0-20 \mathrm{~cm}$ deep) of agricultural crops, a rate that can be considered very high.

The objective of this experiment was to evaluate the response of Epidendrum ibaguense to the application of dolomitic limestone to the growth substrate.

\section{MATERIALS AND METHODS}

Each experimental unit consisted of a 1-L plastic pot containing a layer of $200 \mathrm{~cm}^{3}$ of gravel (gnaissegrain size between 2.3 and $12.7 \mathrm{~mm}$ ) at the bottom and filled up with $800 \mathrm{~cm}^{3}$ defibered xaxim, in which two Epidendrum ibaguense seedlings taken from adult plants were grown. The seedlings were obtained from a field in the Floriculture Sector of the Plant Science Department of the Federal University of Viçosa (UFV).

The experiment, in random blocks with six lime rates and eight replications, was conducted in a greenhouse at the Soil Science Department of the UFV.

Lime was applied to the surface of the substrate at rates of 0.0, 1.0, 2.0, 3.0, 4.0 and $5.0 \mathrm{~g} \mathrm{dm}^{-3}$ based on a total neutralizing power (TNP) of $100 \%$. The lime used had a TNP of $96.4 \%$ with $350 \mathrm{~g} \mathrm{~kg}^{-1}$ of $\mathrm{CaO}$ and $140 \mathrm{~g} \mathrm{~kg}^{-1}$ of MgO. Water was applied to the pot so that the leachate to be collected was approximately $25 \mathrm{~mL}$. The $\mathrm{pH}$ of the soil substrate leachate was measured every two weeks.

The pots were fertigated weekly with a solution containing $2 \mathrm{~g} \mathrm{~L}^{-1}$ of soluble Peters ${ }^{\circledR} 30-10-10+$ micronutrients (N $300 \mathrm{~g} \mathrm{~kg}^{-1}, \mathrm{P} 43.6 \mathrm{~g} \mathrm{~kg}^{-1}, \mathrm{~K}$ $83.0 \mathrm{~g} \mathrm{~kg}^{-1}, \mathrm{Mg} 5 \mathrm{~g} \mathrm{~kg}^{-1}$, B $68 \mathrm{mg} \mathrm{kg}^{-1}$, Fe $500 \mathrm{mg} \mathrm{kg}{ }^{-1}$, $\mathrm{Zn} 22 \mathrm{mg} \mathrm{kg}^{-1}$, Cu $36 \mathrm{mg} \mathrm{kg}^{-1}$, Mn $250 \mathrm{mg} \mathrm{kg}^{-1}$, and Mo $9 \mathrm{mg} \mathrm{kg}^{-1}$ ), applied at a volume of $100 \mathrm{~mL} \mathrm{pot}^{-1}$. The experiment lasted 24 weeks and the total volume of fertigation solution was $2.4 \mathrm{~L} \mathrm{pot}^{-1}$.

The number of leaves and plant height were evaluated at the end of six months when the plants were harvested and the plant material was separated in roots, stems and leaves.
Root, stem and leaf tissues were dried in a forcedair oven at $70^{\circ} \mathrm{C}$, ground and digested (nitric-perchloric acid) for determination of macro and micronutrients. The concentrations of $\mathrm{P}, \mathrm{K}, \mathrm{Ca}, \mathrm{Mg}, \mathrm{S}, \mathrm{Fe}, \mathrm{Mn}, \mathrm{B}$, and $\mathrm{Zn}$ were determined in the nitric-perchloric acid extract by inductively coupled plasma optical emission spectrometry (ICP-OES), and $\mathrm{N}$ by the semi-microKjeldahl method (Embrapa, 1999).

Analyses of variance of the results was carried out with the variables of leaf, stem, root and total dry material, root-to-shoot ratio, number of leaves, leaf weight, average plant height, and $\mathrm{pH}$ of the leachate at variable lime rates. Regression equations were adjusted for the above variables with varying lime rates.

\section{RESULTS AND DISCUSSION}

In general, liming in Epidendrum ibaguense cultivation resulted in a quadratic increase of plant growth (dry matter production). Leaf dry matter production had quadratic behavior with maximum production of $5.5 \mathrm{~g} \mathrm{pot}^{-1}$, obtained at a rate of $4.09 \mathrm{~g} \mathrm{dm}^{-3}$ of lime (Figure 1). This rate is very high, compared with lime applications to crops in agricultural soils in general, which would be equivalent to $8.18 \mathrm{t} \mathrm{ha}^{-1}$ under agricultural field conditions. The rate resulting in the highest dry matter production in stems was similar to that found for leaves: $4.2 \mathrm{~g} \mathrm{dm}^{-3}$ of lime (Figure 1). On the other hand, root dry matter production did not differ significantly according to the lime rates applied (Figure 1).

Total dry matter production (leaves, stems and roots) was equal to $12.14 \mathrm{~g} \mathrm{pot}^{-1}$ at a lime rate of $5 \mathrm{~g} \mathrm{dm}^{-3}$ (Figure 1), which was not expected considering that high lime rates can result in problems as far as solubility and consequent availability of some nutrients (Marschner, 1995; Abreu et al., 2007).

Since the quantity of root dry matter did not vary significantly, the root/shoot ratio (R/AP) was described by a quadratic equation (Figure 1); this ratio decreased with increasing lime rates up to $3.6 \mathrm{~g} \mathrm{dm}^{-3}$, at which the minimum R/AP was found (0.37). At rates of 0 and $5 \mathrm{~g} \mathrm{dm}^{-3}$ the R/AP ratio had values of 0.56 and 0.39 , corresponding to the absence of lime and the maximum productivity observed for dry matter. This ratio is strongly influenced by nutritional characteristics in the medium; values are higher under conditions of limited nutrition and/or other factors that stress the plant (Marschner, 1995).

Despite the large increase in dry matter production, the plant height did not significantly increase with increasing lime rates. Nevertheless, leaves increased significantly for both number of leaves and leaf weight (Figure 1). The lack of significant difference in plant height, despite the increase in number of leaves, can be indicative of $\mathrm{Zn}$ deficiency, 

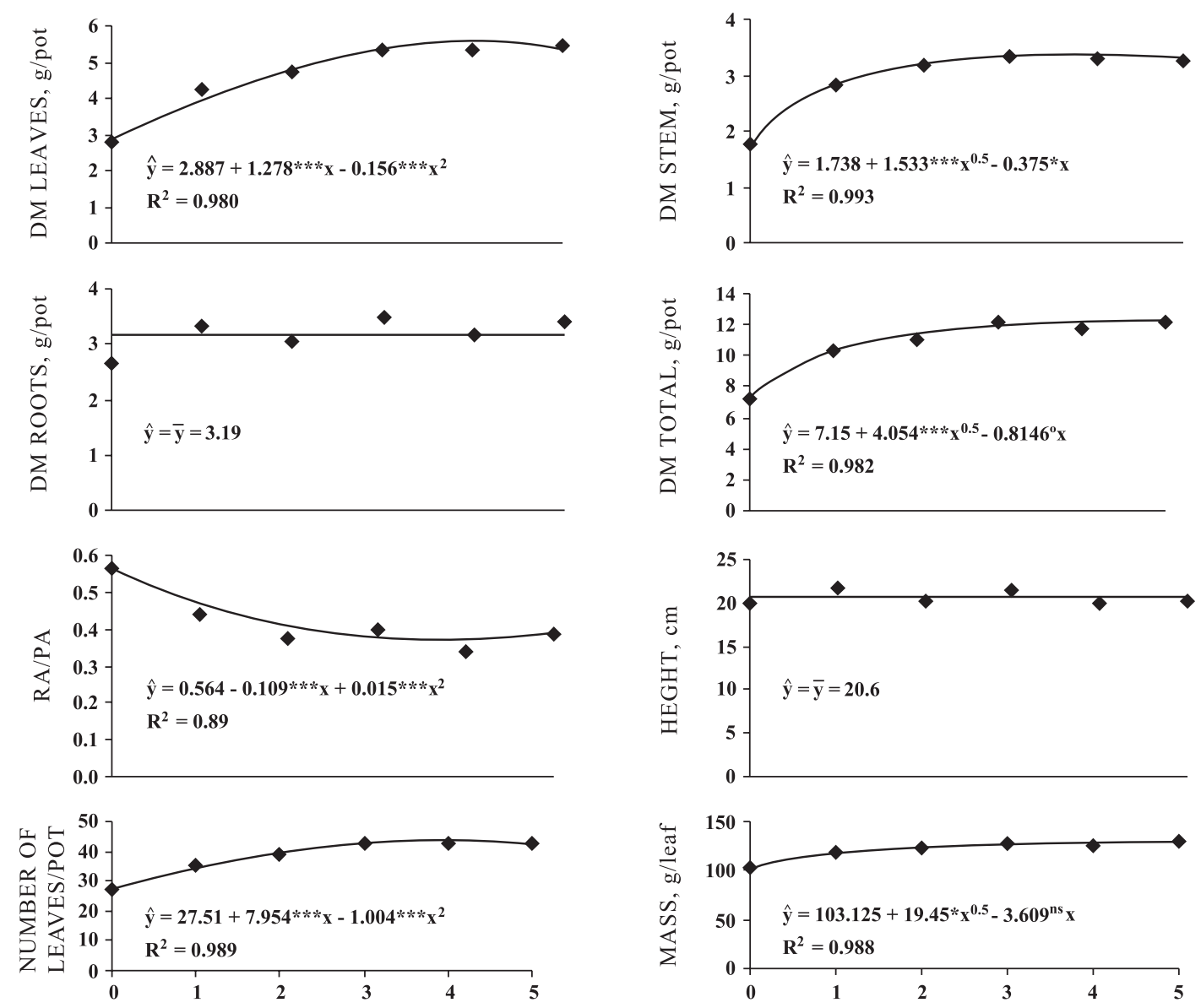

LIME, $\mathrm{g} \mathrm{dm}^{-3}$

Figure 1. Production of leaf, stem, root and total dry matter; root-to-shoot ratio (R/AP); average stem height; number of leaves; and leaf weight in Epidendrum ibaguense at varying lime rates applied to the growth substrate. ${ }^{\circ}, * * * *$ : significant at $10 ; 5 ; 0.1 \%$ and ${ }^{\mathrm{ns}}$ : not significant.

for which one of the principal symptoms is shorter internodes (Römheld \& Marschner, 1991; Abreu et al., 2007).

As expected, lime application increased the $\mathrm{pH}$ level in the leachate of the pots in all treatments; with time, it decreased linearly at rates of 1,2 and $3 \mathrm{~g} \mathrm{dm}^{-3}$, while at rates of 4 and $5 \mathrm{~g} \mathrm{dm}^{-3}$ the values following a cubic square root model (Figure 2). Two weeks after lime application, the $\mathrm{pH}$ values varied from 4.84 to 7.55 (Figure 3) at rates of 0 and $5 \mathrm{~g} \mathrm{dm}^{-3}$, respectively. When the experiment was harvested 168 days later, $\mathrm{pH}$ values were described by a linear equation with values between 4.45 and 6.29 (Figure 3).

The $\mathrm{pH}$ of the growth medium is an important factor for plant nutrition; it has a particularly strong influence on root growth, which is generally favored in slightly acidic (5.5 to 6.5) substrates. At $\mathrm{pH}>7$, the solubility of $\mathrm{P}, \mathrm{Zn}, \mathrm{Fe}, \mathrm{Mn}$ and $\mathrm{B}$ is strongly reduced (Marschner, 1995; Taiz \& Zeiger, 2004; Souza et al., 2007).

The $\mathrm{pH}$ varied even in the control treatment (lime rate 0 ), increasing until the $60^{\text {th }}$ day, to a maximum estimated value of 5.30; shortly after a constant reduction began, reaching 4.29 at the time of harvest (Figure 2), probably as a consequence of loss of bases by leaching.

Since there is no reference for leaf foliar concentrations in plants of the orchid genus Epidendrum, adequate levels of the genus Cattleya were considered for comparison (Jones Jr. et al., 1991).

As this experiment shows, Zn values were inadequate even in the absence of lime (Tables 1 and 2), given the low quantity of substrate and fertilizer used. The range considered adequate is $25-200 \mathrm{mg} \mathrm{kg}^{-1}$ of Zn according to Jones Jr. et al. (1991).

The N concentrations in leaves and stems decreased linearly with the increase of the lime rates [low values when compared to $\mathrm{N}$ levels considered adequate for plants of the genus Cattleya, in the range of 15$25 \mathrm{~g} \mathrm{~kg}^{-1}$ of N (Jones Jr. et al, 1991) (Table 1 and 2)].

Lower $\mathrm{N}$ concentrations in treatments with lime application could have been caused by $\mathrm{N}$ loss by ammonia volatilization from the ammonium in the 

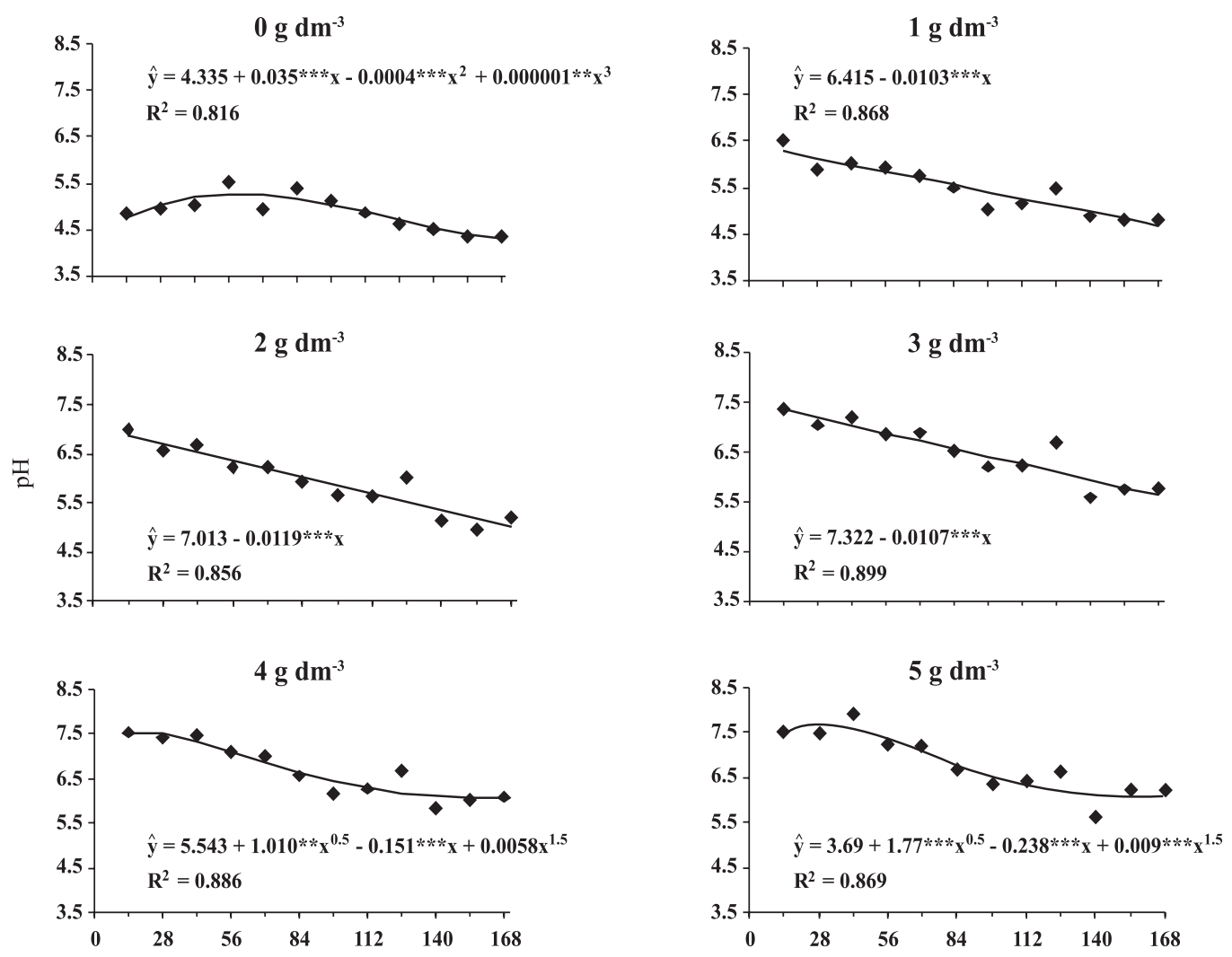

Figure 2. Regression equations of leachate $\mathrm{pH}$ as a variable of time and lime rates $\left(0\right.$ to $\left.5 \mathrm{~g} \mathrm{dm}^{-3}\right) \mathrm{initially}$ applied to the growth substrate. $* *, * * *$ : significant at 1 and $0.1 \%$.

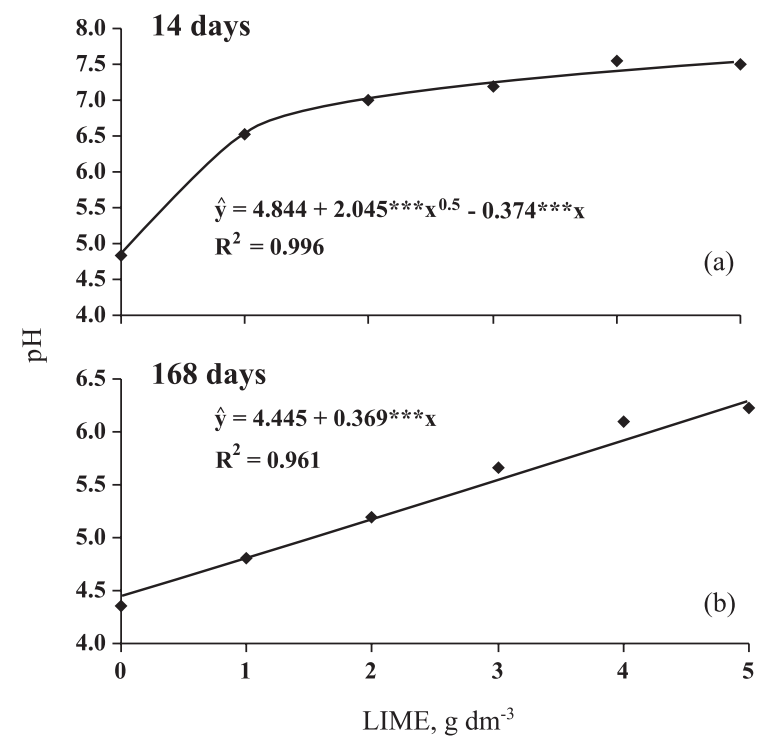

Figure 3. Leachate $\mathrm{pH}$ as a variable of lime rate at 14 (a) and 168 (b) days after application to the growth substrate.

fertilizer applied in the alkaline medium. The equilibrium between $\mathrm{NH}_{4}^{+}$and $\mathrm{NH}_{3}$ is strongly affected by the $\mathrm{pH}$ (Cantarela, 2007); for $\mathrm{pH}$ values of
$6,7,8$ and 9 , the increase in ammonia concentration was 0.1, 1.0, 10 and $50 \%$ (Peoples et al., 1995). Terman (1979) reported even larger losses, from 10 to $50 \%$ of the ammonia applied in the form of urea at $\mathrm{pH}$ from 5.0 to 7.5 , respectively; loss by volatilization was even more pronounced at high temperatures.

Some species of the genus Epidendrum have rapid growth and high flower production throughout most of the year (Moraes, 2004). As a consequence, the nutrient demand of these plants is likely to be different from that observed of the genus Cattleya, which indicates that fertilizer concentrations of determined nutrients can limit plant growth, once the fertilization in this experiment was carried out following general recommendations for orchid fertilization (Novais \& Rodrigues, 2004).

The increasing lime rates on $\mathrm{P}$ concentrations in leaves and roots had a decreasing linear effect (Table 2). However, the concentrations found were within the range considered adequate -1.0 to $7.5 \mathrm{~g} \mathrm{~kg}^{-1}$ (Jones Jr. et al., 1991).

Concentrations of $\mathrm{K}$ did not vary significantly in leaves and stems, with average values of 24 and $10 \mathrm{~g} \mathrm{~kg}^{-1}$, respectively (Table 1 ). In the case of roots, $\mathrm{K}$ concentrations decreased slightly, following a linear model (Table 2). 
Table 1. Concentrations of macro and micronutrients in leaves, stems and roots of Epidendrum ibaguense in response to lime rates applied to the growth substrate

\begin{tabular}{|c|c|c|c|c|c|c|c|c|c|c|}
\hline Dose of liming & $\mathbf{N}$ & $\mathbf{P}$ & $\mathbf{K}$ & $\mathbf{C a}$ & Mg & $\mathbf{S}$ & $\mathrm{Fe}$ & Mn & $\mathrm{Zn}$ & B \\
\hline \multirow[t]{2}{*}{$\mathrm{g} \mathrm{dm}-3$} & \multicolumn{6}{|c|}{$-\mathrm{g} \mathrm{kg}^{-1}$} & \multicolumn{4}{|c|}{$\mathrm{mg} \mathrm{kg}^{-1}$} \\
\hline & \multicolumn{10}{|c|}{ Leaf } \\
\hline 0.00 & 16.27 & 2.00 & 25.19 & 3.81 & 2.24 & 0.10 & 116.8 & 121.6 & 22.4 & 45.9 \\
\hline 1.00 & 15.65 & 1.93 & 22.74 & 12.85 & 4.78 & 0.09 & 95.3 & 99.3 & 21.6 & 36.0 \\
\hline 2.00 & 14.48 & 1.86 & 25.17 & 16.39 & 5.32 & 0.09 & 80.0 & 81.0 & 20.5 & 31.6 \\
\hline 3.00 & 14.35 & 1.75 & 24.18 & 17.88 & 5.41 & 0.08 & 81.7 & 63.1 & 18.1 & 25.1 \\
\hline 4.00 & 13.48 & 1.63 & 21.75 & 19.60 & 5.61 & 0.08 & 79.1 & 57.4 & 17.0 & 20.5 \\
\hline \multirow[t]{2}{*}{5.00} & 13.08 & 1.67 & 24.90 & 19.91 & 5.69 & 0.08 & 82.9 & 58.3 & 17.4 & 20.1 \\
\hline & \multicolumn{10}{|c|}{ Stem } \\
\hline 0.00 & 14.31 & 0.97 & 8.47 & 2.07 & 0.94 & 0.03 & 40.8 & 47.8 & 12.7 & 54.6 \\
\hline 1.00 & 15.65 & 0.87 & 9.59 & 3.10 & 1.43 & 0.03 & 32.0 & 25.6 & 9.9 & 35.6 \\
\hline 2.00 & 14.48 & 0.91 & 10.98 & 3.68 & 1.78 & 0.03 & 29.4 & 22.2 & 10.4 & 33.2 \\
\hline 3.00 & 14.35 & 0.90 & 11.60 & 4.22 & 1.97 & 0.03 & 31.0 & 16.9 & 8.7 & 29.0 \\
\hline 4.00 & 13.48 & 0.85 & 10.00 & 4.27 & 1.91 & 0.03 & 27.3 & 14.0 & 9.3 & 30.8 \\
\hline \multirow[t]{2}{*}{5.00} & 13.08 & 0.92 & 12.21 & 4.82 & 2.11 & 0.03 & 24.1 & 15.1 & 9.3 & 32.4 \\
\hline & \multicolumn{10}{|c|}{ Root } \\
\hline 0.00 & 12.56 & 1.42 & 6.32 & 1.42 & 0.78 & 2.19 & 588.1 & 29.9 & 58.8 & 46.2 \\
\hline 1.00 & 11.65 & 1.31 & 7.55 & 2.38 & 1.80 & 2.09 & 363.4 & 17.3 & 52.0 & 38.7 \\
\hline 2.00 & 13.91 & 1.33 & 8.68 & 3.12 & 2.50 & 2.02 & 365.2 & 15.0 & 51.6 & 38.4 \\
\hline 3.00 & 13.53 & 1.17 & 8.56 & 3.38 & 2.70 & 2.02 & 333.2 & 13.8 & 52.8 & 35.1 \\
\hline 4.00 & 12.58 & 1.22 & 8.75 & 4.04 & 3.12 & 2.01 & 325.8 & 11.6 & 30.1 & 33.8 \\
\hline 5.00 & 13.64 & 1.21 & 9.40 & 4.39 & 3.23 & 1.99 & 308.0 & 9.8 & 30.5 & 37.2 \\
\hline
\end{tabular}

In all plant components, the Ca concentrations (Tables 1 and 2) increased significantly with the lime rates; in the treatment without liming the plant content was $3.81 \mathrm{~g} \mathrm{~kg}^{-1}$, below the level considered adequate for genus Cattleya: 6-20 $\mathrm{g} \mathrm{kg}^{-1}$ (Arditti, 1992). The principal effect of lime application in this experiment was as a supplement of $\mathrm{Ca}$, in view of the absence of this nutrient in the majority of soluble fertilizer mixtures used in orchid fertigation.

Magnesium behaved similarly to $\mathrm{Ca}$ (Table 1); the plant concentration observed in the treatment without liming was lower $\left(2.26 \mathrm{~g} \mathrm{~kg}^{-1}\right)$ than what is considered adequate: 4-7 g kg-1 for Cattleya (Jones Jr et al., 1991).

Because of the absence of $\mathrm{S}$ in Peters ${ }^{\circledR}$ fertilizers, the level of this nutrient decreased linearly with the increase of lime rates given the increase in dry matter production and consequently, $\mathrm{S}$ dilution in tissues. At all lime rates, $\mathrm{S}$ concentrations were far below what is considered adequate for Cattleya: 1.5 to $7.5 \mathrm{~g} \mathrm{~kg}^{-1}$ (Jones Jr et al., 1991); the highest concentration, of $0.1 \mathrm{~g} \mathrm{~kg}^{-1}$ (Table 1), was found in the treatment without liming where dry matter production was consequently the lowest.

Plant concentrations of Fe, Zn, Mn and B (Table 1 and 2) decreased in response to lime rate; the Fe and Mn concentrations remained within the ranges considered adequate for Cattleya: 50-200, 25-200, 40200, and 25-75 mg kg-1, respectively (Jones Jr et al.,
1991). Most likely, Fe and Mn deficiency were not observed due to the elevated concentrations of these nutrients in xaxim: 1,593 and $62 \mathrm{mg} \mathrm{kg}^{-1}$, respectively (Novais \& Rodrigues, 2004).

Zinc concentrations were low ( $\left.22.4 \mathrm{mg} \mathrm{kg}^{-1}\right)$, even in the treatments without liming; lime application aggravated a probable $\mathrm{Zn}$ deficiency, leading to the absence of variation between the plants (Table 1 and Figure 1). Zinc deficiency is characterized by a decrease in internodal growth, with rosette growth, and the leaves can be small, wrinkled and twisted along the edges. These symptoms are principally a result from the loss of production capacity of sufficient levels of auxin -indole-3-acetic acid (AIA) (Taiz \& Zeiger, 2004).

Boron concentrations in leaves were inadequate from the penultimate rate of lime $\left(<25 \mathrm{mg} \mathrm{kg}^{-1}\right)$ (the ideal range for Cattleya is 25-75 $\mathrm{mg} \mathrm{kg}^{-1}$; Jones Jr. et al., 1991). Curiously, the B concentrations found in roots and stems had higher values than in leaves. For the stem, this is probably due to B being a constituent of cell membranes and principally walls, of fundamental importance for the plant sustenance (Marschner, 1995).

Iron concentrations found in roots were very high; this nutrient is probably deposited along with the velamen. Lime application also caused a strong decrease in the concentration of this nutrient in tissues (Tables 1 and 2). 
Table 2. Regression equations adjusted for concentrations of macro $\left(\mathrm{g} \mathrm{kg}^{-1}\right)$ and micronutrients $\left(\mathrm{mg} \mathrm{kg}^{-1}\right)$ in leaves, stems and roots of Epidendrum ibaguense as a variable of lime rates $\left(\mathrm{g} \mathrm{dm}^{-3}\right)$ applied to the growth substrate

\begin{tabular}{|c|c|c|}
\hline Nutrient & Equation & $\mathbf{R}^{2}$ \\
\hline \multicolumn{3}{|c|}{ Leaf } \\
\hline $\mathrm{N}$ & $\hat{y}=16.16-0.645^{* * *} x$ & 0.970 \\
\hline $\mathrm{P}$ & $\hat{y}=2.000-0.0767^{* * *} x$ & 0.935 \\
\hline $\mathrm{K}$ & $\hat{y}=\bar{y}=23.99$ & - \\
\hline $\mathrm{Ca}$ & $\hat{y}=3.741+11.136^{* * *} x^{0.5}-1.690^{* *} x$ & 0.999 \\
\hline $\mathrm{Mg}$ & $\hat{y}=2.256+3.241^{* * *} x^{0.5}-0.776^{* * *} \mathrm{x}$ & 0.997 \\
\hline $\mathrm{S}$ & $\hat{y}=0.096-0.004^{*} x$ & 0.767 \\
\hline $\mathrm{Fe}$ & $\hat{y}=117.593-35.66^{* * *} x^{0.5}+8.607^{*} x$ & 0.955 \\
\hline $\mathrm{Zn}$ & $\hat{y}=22.445-1.180^{* * *} \mathrm{x}$ & 0.919 \\
\hline $\mathrm{Mn}$ & $\hat{y}=122.838-27.958^{* * *} \mathrm{x}+2.963^{* * *} \mathrm{x}^{2}$ & 0.995 \\
\hline B & $\begin{array}{c}\hat{\mathrm{y}}=42.858-5.201^{* * *} \mathrm{x} \\
\text { Stem }\end{array}$ & 0.934 \\
\hline $\mathrm{N}$ & $\hat{y}=17.044-1.336^{*} x^{0.5}-0.200^{n s} x$ & 0.976 \\
\hline $\mathrm{P}$ & $\hat{\mathrm{y}}=\bar{y}=0.90$ & - \\
\hline $\mathrm{K}$ & $\hat{\mathrm{y}}=\bar{y}=10.47$ & - \\
\hline $\mathrm{Ca}$ & $\hat{y}=2.058+0.996^{*} x^{0.5}+0.097^{n s} x$ & 0.989 \\
\hline $\mathrm{Mg}$ & $\hat{y}=0.925+0.632 * x^{0.5}-0.047^{n s} x$ & 0.970 \\
\hline $\mathrm{S}$ & $\hat{y}=0.033-0.006^{*} x^{0.5}+0.002^{\mathrm{ns}} \mathrm{x}$ & 0.778 \\
\hline $\mathrm{Fe}$ & $\hat{y}=37.61-2.749^{* *} \mathrm{x}$ & 0.821 \\
\hline $\mathrm{Zn}$ & $\hat{y}=12.699-3.228^{* *} x^{0.5}+0.745^{n s} x$ & 0.894 \\
\hline $\mathrm{Mn}$ & $\hat{y}=47.778-26.648^{* * *} x^{0.5}+5.217^{* *} x$ & 0.992 \\
\hline B & $\begin{array}{c}\hat{\mathrm{y}}=54.653-26.270^{* * *} \mathrm{x}^{0.5}+7.188^{*} \mathrm{x} \\
\text { Root }\end{array}$ & 0.988 \\
\hline $\mathrm{N}$ & $\hat{\mathrm{y}}=\bar{y}=12.98$ & \\
\hline $\mathrm{P}$ & $\hat{y}=1.361-0.0377^{* *} \mathrm{x}$ & 0.576 \\
\hline $\mathrm{K}$ & $\hat{y}=7.09+0.37^{*} \mathrm{x}$ & 0.536 \\
\hline $\mathrm{Ca}$ & $\hat{y}=1.415+0.746^{* *} x^{0.5}+0.266^{*} x$ & 0.990 \\
\hline $\mathrm{Mg}$ & $\hat{y}=0.764+1.164^{* * *} x^{0.5}-0.01442^{\mathrm{ns}} \mathrm{x}$ & 0.991 \\
\hline S & $\hat{y}=\bar{y}=2.05$ & - \\
\hline $\mathrm{Fe}$ & $\hat{y}=583.199-255.134^{* * *} x^{0.5}+61.541^{* *} x$ & 0.975 \\
\hline $\mathrm{Zn}$ & $\hat{y}=60.676-5.885^{* *} x$ & 0.785 \\
\hline $\mathrm{Mn}$ & $\hat{y}=29.643-13.692^{* * *} x^{0.5}+2.279^{*} x$ & 0.990 \\
\hline B & $\hat{y}=45.761-6.327^{* *}$ & 0.923 \\
\hline
\end{tabular}

$\circ, * * *, * * *$ : significant at $10 ; 5 ; 1$ and $0.1 \%$.

\section{CONCLUSIONS}

1. Production of leaf and stem dry matter increased significantly in response to the lime rates; in the case of roots there was no significant difference.

2. The $\mathrm{pH}$ in the substrate leachate from the pots decreased over the course of time.

3. Foliar concentrations of N, P, S, Fe, Zn, Mn and $\mathrm{B}$ decreased in response to increasing lime applications to the substrate.

\section{LITERATURE CITED}

ABREU, C.A.; LOPES, A.S. \& SANTOS, G.C.G. Micronutrientes In: NOVAIS, R.F.; ALVAREZ V., V.H.; BARROS, N.F.; FONTES, R.L.F.; CANTARUTTI, R.B. \& NEVES, J.C.L., eds. Fertilidade do solo.Viçosa, MG, Sociedade Brasileira de Ciência do Solo, 2007. p.645-736.

AMBERGER-OCHSENBAUER, S. Nutrition and postproduction performance of Phalaenopsis pot plants. Acta Hortic., 450:105-112, 1997.

ARDITTI, J. Fundamentals of orchid biology. New York, John Wiley \& Sons, 1992. 691p.

CANTARELLA, H. Nitrogênio In: NOVAIS, R.F.; ALVAREZ V., V.H.; BARROS, N.F.; FONTES, R.L.F.; CANTARUTTI, R.B. \& NEVES, J.C.L., eds. Fertilidade do solo. Viçosa, MG, Sociedade Brasileira de Ciência do Solo, 2007. 1017p.

CASTRO, C.E.F. Cadeia produtiva de flores e plantas ornamentais. R. Bras. Hortic. Ornam., 4:1-46, 1998.

DEMUNDO, F.A. Phalaenopsis. O mundo das orquídeas, 35:6$10,2004$.

EMPRESA BRASILEIRA DE PESQUISA AGROPECUÁRIA EMBRAPA. Manual de análises químicas de solos, plantas e fertilizantes. Brasília, Embrapa Comunicação para Transferência de Tecnologia, 1999. 370p.

JONES Jr, J.B.; WOLF, B. \& MILLS, H.A. Plant analysis handbook. Athens, Micro-Macro Publishing, 1991. 213p.

JUNQUEIRA, A.H. \& PEETZ, M.S. Mercado interno para os produtos da floricultura brasileira: Características, tendências e importância socioeconômica recente. R. Bras. Hortic. Ornam., 14:37-52, 2008.

MARSCHNER, H. Mineral nutrition of higher plants. London, Academic Press, 1995. 888p.

MATSUnAGA, M. Potencial da floricultura brasileira. Agroanalysis, 15:56, 1995.

MORAES, P.J. Crescimento, caracterização da abertura floral e manejo pós-colheita de flores de Epidendrum ibaguense Kunt. Viçosa, MG, Universidade Federal de Viçosa, 2004. 110p. (Tese de Doutorado)

NOVAIS, R.F. \& RODRIGUES, D.T. Nutrição e fertilização de orquídeas. In: CONGRESSO BRASILEIRO DE BOTÂNICA, 2004, Viçosa, MG. Simpósios Palestras e Mesas Redondas. Viçosa, MG, Sociedade Botânica do Brasil, 2004.

PEOPLES, M.B.; FRENEY, J.R. \& MOSIER, A.R. Minimizing gaseous losses of nitrogen. In: BACON, P.E., ed. Nitrogen fertilization in the environment. New York, Marcel Dekker, 1995. p.565-602.

RÖMHELD, V. \& MARSCHNER, H. Function of micronutrients in plants. In: MORDVET, J.J.; GIORDANO, P.M. \& LINDSAY, W.L. eds. Micronutrients in agriculture. Madison, Soil Science Society of America, 1991. p.703719 . 
SOUZA, D.M.G.; MIRANDA, L.N. \& OLIVEIRA, A.S. Acidez do solo e sua correção. In: NOVAIS, R.F.; ALVAREZ V., V.H.; BARROS, N.F.; FONTES, R.L.F.; CANTARUTTI, R.B. \& NEVES, J.C.L., eds. Fertilidade do solo. Viçosa, MG, Sociedade Brasileira de Ciência do Solo, 2007. p.205274 .

TAIZ, L. \& ZEIGER, E. Fisiologia vegetal. Porto Alegre, Artmed, 2004. 719 p.

TERMAN, G.L. Volatilization losses of nitrogen as ammonia from surface-applied fertilizer, organic amendments, and crop residues. Adv. Agron., 31:189-223, 1979.
WANG, Y.T. \& GREGG, L.L. Medium and fertilizer affect the performance of Phalaenopsis orchids during two flowering cycles. Hortic. Sci., 29:269-271, 1994.

WANG, Y.T. Effects of six fertilizers on vegetative growth and flowering of Phalaenopsis orchids. Sci. Hortic., 65:191-197, 1996.

WANG, Y.T. Impact of a high phosphorus fertilizer and timing of termination of fertilization on flowering of a hybrid of moth orchid. Hortic. Sci., 35:60-62, 2000. 